Table IV, Table V および Table VI の結果も当然 と考えられる.

また，合成值と分析值との一致の得られたことから， 試料導入が良好飞行なわれており, 試料留での特定成分 の吸着もあまりないものと考えられる．ただし，この合 成試料の測定は試料の吸着の項で述べた実験をしたのち に行なったもので, 試料導入系は炭化水素を十分吸着し た状態であると考えられ，長期間使用していない試料導 入系で合成試料を測定する場合は注意する必要がある う.

分析管内での高質量炭化水素の吸着はあまり問題はな く，30 分の排気でバックグラウンドは $\mathrm{M} / \mathrm{e} 18$ および M/e 44 が少量と炭化水素のピークが若干認められる程 度である. 今回の測定による分解能の低下およびイオン 源の特性変化はなかった。

最後に，本実験觉行なうにあたって，御協力下さった 日立製作所那珂工場牧野勇夫部長扣よび質量分析計担当 のかたがたに感謝いたします。

（昭和 37 年 4 月,日本化学会第 15 年会に扎いて発表）

\section{交献}

1) R. A. Brown : Anal. Chem., 23, 430 (1951).

2) H. Sobcov : ibid., 24, 1306 (1952).

3) A. R. Glasgow, R. J. Gordon, C. B. Willingham, B. J. Mair, F. D. Rossini : ibid., 29, 357 (1957).

4) M. B. Epstein, C. B. Willingham, B. J. Mair, F. D. Rossini : ibid., 28, 1924 (1956).

5) H. E. Lumpkin, B. H. Johnson : ibid., 28, 306 (1956).

6) M. J. O'Neal, T. P. Wier : ibid., 23, 830 (1951).

7) R. J. Clerc, A. Hood, M. J. O'Neal : ibid., 27, 868 (1955).
8) H. E. Lumpkin : ibid., 28, 1946 (1956).

9) M. L. André, M. J. O’Neal : ibid., 31, 164 (1959).

10) R. A. Brown, D. J. Skahan, V. A. Cirillo, F. W. Melpolder : ibid., 31, 1531 (1959).

11) F. H. Field, S. H. Hastings : ibid., 28, 1248 (1956).

12) G. L. Kearns, N. C. Maranowski, G. F. Crable : ibid., 31, 1646 (1959).

13) R. C. Taylor, W. S. Yong : Ind. Eng. Chem., 17, 811 (1945).

14) R. A. Friedel, A. G. Sharkey, C. R. Humbert: Anal. Chem., 21, 1572 (1949).

15) K. M. Purdy, R. J. Harris : ibid., 22, 1337 (1950).

16) S. Meyerson : ibid., 25, 338 (1953).

17) V. A. Yarborough : ibid., 25, 1914 (1953).

18) V. J. Caldecourt : ibid., 27, 1670 (1955).

19) E. H. Rowe : Rev. Scientific Inst., 28, 1094 (1957).

$$
\text { ז }
$$

Mass spectrometry for paraffines. Shozo Oshima and Akira Katsumata (Research Center, Maruzen Oil Co.)

A method for measuring mass spectra of highmass hydrocarbons has been presented. A special device is given for introducing samples in the instrument, where liquid hydrocarbon taken by a micropipet in a stainless steel bottle is heated and introduced by the evaporation into a sample vessel. Suitable conditions for evaporation of sample out of the bottle and absorption of it by the vessel are sought for to obtain high reproducibility of the mass spectra.

The mass spectra of $\mathrm{C}_{6} \sim \mathrm{C}_{22}$ paraffins and the development of a method for analyzing normalparaffin by molecular ion indicates a possibility of the analysis of normal-paraffins with high accuracy.

(Received Apr. 13, 1962)

\title{
質量分析法によるノルマルパラフィン とイソパラフィンのタイプ分析法
}

\author{
大島 昌 三*
}

側鎖を 2 個以上有するイソパラフィンが共存しないパラフィン系炭化水素をノルマルパラフィンとイ ソパラフィンにタイプ分析する質量分析法を報告したが，その報告では $\mathrm{C}_{6}$ から $\mathrm{C}_{11}$ までについて検討 したものであった．高分解能の質量分析計执よび高温試料導入系を使用して $\mathrm{C}_{22}$ までのパラフィン系炭 化水素の質量スペクトルを測定した。 その結果, $\mathrm{C}_{n} \mathrm{H}_{2 n}{ }^{+}$のイオン量の $\mathrm{M} / \mathrm{e} 42$ 以上の合計值（ただ し，イオン量はノルマルヘキサンの M/e 57 を基準ピークにした相対ピーク量）と分子イオンによるタ イプ分析法が $\mathrm{C}_{12}$ 以上 $\mathrm{C}_{22}$ までのパラフィン系炭化水素に適用できるとと認めた。

また， $\Sigma 41, \Sigma 42 ， \Sigma 43$ ，分子イオンおよび質量スペクトルの図型について若干の知見を得た. 


\section{1 緒論}

パラフィン系炭化水素をノルマルパラフィン㧍よびイ ソパラフィンにタイプ分析する方法としてはいくつかの 分析法1) 4) があるが，いずれも欠点を持っており，ま た，質量分析によって行なう方法もすでに報告されてい る5)6) が， $\mathrm{C}_{6}$ から $\mathrm{C}_{11}$ までの炭化水素に応用しうるもの である、また，著者はイソパラフィンとしては，側鎖を 1 個有する異性体の名まれているパラフィン系炭化水 素をノルマルパラフィンとイソパラフィンにタイプ分析 する方法定報告7した。この方法はイソパラフィンに側 鎖が 2 個以上のものが含まれていない試料では分析精度 が最も良好であるが，炭素数の適用範囲としては $\mathrm{C}_{6}$ か ら $\mathrm{C}_{11}$ 东であった。しかし，この分析法の検討において 使用した質量分析計注分解能が小さく，また，試料導入 系がガラス製で加熱が不可能であったために， $\mathrm{C}_{6}$ から $\mathrm{C}_{9}$ までの炭化水素の質量スペクトルを測定し，それ以 上のものについては文献のデータを用いて考察したもの である。

著者は $\mathrm{C}_{12}$ 以上の炭化水素にもこの分析法定適用しう るか否かを检討する目的で, 分解能の高い質量分析計を 用い, $\mathrm{C}_{22}$ までの炭化水素の質量スペクトルを測定した.

その結果, $\mathrm{C}_{12}$ 以上 $\mathrm{C}_{22}$ までの炭化水素にも適用しう ること劣認め，さらに質量スペクトルについて考察し若 干の知見を得たので報告する。

\section{2 実験}

\section{$2 \cdot 1$ 質量分析計および測定法}

測定に使用した質量分析計は日立製 RMU-5B型質量 分析計で, 分析管半径が $200 \mathrm{~mm}$.の $90^{\circ}$ 型のものであ る. 試料の導入はステンレス製試験管型の試料びんに液 状にてマイクロピペットで入れ，この試料びえを $150^{\circ} \mathrm{C}$ に加熱保持してある試料導入系に取付け, ヒーターで加 熱して試料留に蒸発させた. 装置および測定法はすでに 報告した方法8)と同一であるので詳細は省略する。

\section{$2 \cdot 2$ 標準試料}

測定した炭化水素は $\mathrm{C}_{6}, \mathrm{C}_{8}, \mathrm{C}_{10}, \mathrm{C}_{12}, \mathrm{C}_{14}, \mathrm{C}_{16}, \mathrm{C}_{18}$, $\mathrm{C}_{20}$ および $\mathrm{C}_{22}$ のノルマルパラフィンおよび2-メチルヘ

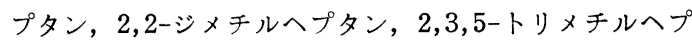
タンおよび 2-メチルデカンで，いずれも A.P.I. の標 準試料である.

$$
3 \text { 結 果 }
$$

測定した炭化水素の質量スペクトルから，ノルマルヘ
キサンの $\mathrm{M} / \mathrm{e} 57$ を 100 とした相詨ピーク值を求め, 考察に必要な $\mathrm{C}_{n} \mathrm{H}_{2 n-1}{ }^{+}, \mathrm{C}_{n} \mathrm{H}_{2 n}{ }^{+}$および $\mathrm{C}_{n} \mathrm{H}_{2 n+1}+$ の 3 組の值を表にしたものが Table I である. M/e $i$ に おける $j$ 成分のパタン係数を $a_{i j}$ とし， $j$ 成分の基準ピ 一クの感度を $S_{j}$, ノルマルヘキサンの M/e 57 （基準 ピーク）の感度を $S_{\mathrm{hex}}$ とする, 各炭化水素の相対ピ 一ク值は $a_{i} S_{j} / S_{\mathrm{hex}}$ で求まる.

\section{4 考察}

著者はさきにパラフィン采炭化水素のうち， $\mathrm{C}_{6}$ 多ら $\mathrm{C}_{9}$ までの炭化水素（イソパラフィンは $\mathrm{C}_{6}$ から $\mathrm{C}_{8}$ 安 で）の質量スペクトルを測定し，ノルマルパラフィンと イソパラフィンとの分子ィオンの比較およびノルマルヘ キサンの M/e 57 を 100 とした相対ピーク量のうち, M/e 41 以上について $\Sigma 41 ， \sum 42$ および $\Sigma 43$ を求 めて考察した結果を報告し，分子イオンおよび りノルマルパラフィンと側鎖が 1 個のイソパラフィンと のタイプ分析法を示した。 また， $\mathrm{C}_{9}$ 以上については交 献のデータを用い，このタイプ分析法が $\mathrm{C}_{11}$ まで邉用で きることを認めた7)。本報告では， $\mathrm{C}_{6}$ から $\mathrm{C}_{22}$ までの 炭素数が偶数のノルマルパラフィンおよび $\mathrm{C}_{8}$ から $\mathrm{C}_{11}$ までの 4 個のイソパラフィンについて測定した質量スパ クトルから, 前報告のタイプ分析法の $\mathrm{C}_{12}$ 以上への適用 の可能なことおよびその他質量スペクトルの特性につい て考察する.

なお， $\Sigma 41 ， \Sigma 42$ および $\Sigma 43$ とは，

$\mathrm{M} / \mathrm{e} 41=1, \mathrm{M} / \mathrm{e} 55=2, \mathrm{M} / \mathrm{e} 69=3, \mathrm{M} / \mathrm{e} 83=4$,

$\mathrm{M} / \mathrm{e} 42=1^{\prime}, \mathrm{M} / \mathrm{e} 56=2^{\prime}, \mathrm{M} / \mathrm{e} 70=3^{\prime}, \mathrm{M} / \mathrm{e} 84=4^{\prime}$,

$\mathrm{M} / \mathrm{e} 43=1^{\prime \prime}, \mathrm{M} / \mathrm{e} 57=2^{\prime \prime}, \mathrm{M} / \mathrm{e} 71=3^{\prime \prime}, \mathrm{M} / \mathrm{e} 85=4^{\prime \prime}$, とすると

$$
\begin{aligned}
& \sum 41=\sum_{l=1}^{m} \frac{a_{l j} S_{j}}{S_{\mathrm{hex}}} \\
& \sum 42=\sum_{l^{\prime}=1^{\prime}}^{m} \frac{a_{l^{\prime} j} S_{j}}{S_{\mathrm{hex}}} \\
& \Sigma 43=\sum_{l^{\prime \prime}=1^{\prime \prime}}^{m} \frac{a_{l^{\prime \prime} j} S_{j}}{S_{\mathrm{hex}}}
\end{aligned}
$$

\section{$4 \cdot 1 \quad \Sigma 41$ および $\Sigma 43$}

Table I から $\Sigma 41, \Sigma 42$ および $\Sigma 43$ を求め, Table II にまとめて示し, 前報告の值を Table III に 記した. 
Table I パラフィン系炭化水素の $a_{i} S_{j} / S_{\mathrm{hex}}$ の值

\begin{tabular}{|c|c|c|c|c|c|c|c|c|c|c|c|c|c|}
\hline $\mathrm{M} / \mathrm{e}$ & $\stackrel{n-}{\mathrm{C}_{6}} \mathrm{H}_{14}$ & $\stackrel{n-}{\mathrm{C}_{8} \mathrm{H}_{18}}$ & $\stackrel{n-}{\mathrm{C}_{10} \mathrm{H}_{22}}$ & $\stackrel{n-}{\mathrm{C}_{12}} \mathrm{H}_{26}$ & $\stackrel{n-}{\mathrm{C}_{14} \mathrm{H}_{30}}$ & $\stackrel{n-}{\mathrm{C}_{16} \mathrm{H}_{34}}$ & $\stackrel{n-}{\mathrm{C}_{18} \mathrm{H}_{38}}$ & $\stackrel{n-}{\mathrm{C}_{20} \mathrm{H}_{42}}$ & $\stackrel{n-}{\mathrm{C}_{22}} \mathrm{H}_{46}$ & $\begin{array}{l}2 \text {-methyl } \\
\text { heptane }\end{array}$ & $\begin{array}{l}2,2- \\
\text { dimethyl } \\
\text { heptane }\end{array}$ & $\begin{array}{l}3,3,5- \\
\text { trimethyl } \\
\text { heptane }\end{array}$ & $\begin{array}{l}2 \text {-methyl } \\
\text { decane }\end{array}$ \\
\hline 41 & 76.6 & 68.99 & 60.37 & 62.27 & 76.22 & 73.10 & 69.46 & 72.63 & 62.20 & 69.17 & 59.14 & 45.93 & 97.51 \\
\hline 42 & 39.7 & 25.48 & 21.23 & 19.58 & 20.54 & 18.56 & 17.66 & 18.58 & 16.05 & 59.16 & 5.74 & 7.91 & 40.80 \\
\hline 43 & 71.5 & 149.00 & 121.00 & 112.00 & 140.20 & 139.06 & 136.10 & 142.20 & 133.02 & 145.00 & 35.72 & 94.88 & 172.04 \\
\hline 55 & 9.06 & 18.33 & 22.49 & 29.03 & 32.07 & 35.24 & 38.94 & 43.29 & 46.76 & 24.22 & 11.16 & 24.42 & 27.47 \\
\hline 56 & 43.7 & 30.84 & 20.84 & 23.80 & 24.60 & 22.73 & 23.52 & 24.04 & 25.35 & 14.21 & 83.72 & 6.81 & 26.79 \\
\hline 57 & 100.0 & 49.77 & 100.15 & 108.00 & 148.00 & 151.00 & 153.00 & 155.00 & 151.00 & 111.80 & 192.00 & 100.50 & 136.00 \\
\hline 69 & 0.52 & 2.07 & 8.51 & 12.12 & 12.46 & 14.13 & 17.43 & 20.06 & 24.42 & 1.75 & 2.62 & 9.58 & 8.91 \\
\hline 70 & 1.34 & 18.92 & 16.73 & 19.02 & 17.14 & 16.05 & 16.75 & 13.31 & 17.58 & 23.64 & 2.30 & 45.93 & 14.01 \\
\hline 71 & 5.76 & 34.87 & 36.22 & 52.38 & 83.61 & 88.50 & 93.62 & 94.26 & 93.38 & 36.54 & 33.80 & 160.20 & 80.51 \\
\hline 83 & 0.01 & 0.03 & 3.29 & 7.34 & 6.44 & 7.87 & 10.63 & 11.86 & 17.18 & 1.96 & 0.20 & 3.35 & 6.79 \\
\hline 84 & 0.30 & 10.97 & 11.80 & 10.56 & 10.64 & 9.78 & 10.36 & 9.13 & 11.25 & 3.78 & 0.24 & 1.15 & 6.45 \\
\hline 85 & 0.94 & 47.38 & 28.27 & 30.81 & 51.56 & 55.52 & 62.27 & 60.62 & 63.45 & 6.64 & 0.64 & 8.75 & 37.54 \\
\hline 97 & & 0.01 & 1.92 & 3.90 & 3.71 & 5.06 & 7.22 & 8.79 & 12.71 & 1.90 & 0.14 & 0.74 & 1.17 \\
\hline 98 & & 0.06 & 5.76 & 6.56 & 7.53 & 6.98 & 7.21 & 7.42 & 4.83 & 6.64 & 0.14 & 0.53 & 0.90 \\
\hline 99 & & 0.03 & 7.41 & 6.34 & 11.50 & 13.98 & 16.78 & 16.68 & 18.62 & 21.32 & 0.06 & 0.42 & 10.01 \\
\hline 111 & & 0 & 0.54 & 1.22 & 1.38 & 2.17 & 3.41 & 4.34 & 6.64 & 0.07 & 0.10 & 0.11 & 0.27 \\
\hline 112 & & 0.04 & 2.47 & 5.78 & 5.54 & 5.19 & 5.58 & 5.80 & 6.40 & 0.12 & 0.38 & 4.08 & 19.31 \\
\hline 113 & & 0.09 & 4.94 & 5.01 & 7.53 & 9.06 & 11.23 & 10.93 & 12.52 & 0.17 & 10.08 & 21.91 & 20.81 \\
\hline 125 & & & 0.02 & 0.34 & 0.37 & 0.85 & 1.47 & 1.95 & 3.11 & & 0 & 0.16 & 0.04 \\
\hline 126 & & & 0.01 & 1.89 & 3.77 & 3.97 & 4.24 & 4.05 & 4.61 & & 0 & 0.17 & 0.22 \\
\hline 127 & & & 0.16 & 4.11 & 6.39 & 6.78 & 8.35 & 8.34 & 9.35 & & 0 & 3.41 & 0.35 \\
\hline 139 & & & 0 & 0.56 & 0.09 & 0.23 & 0.52 & 0.81 & 1.51 & & & 0 & 0.26 \\
\hline 140 & & & 0.81 & 1.33 & 2.55 & 3.02 & 3.46 & 3.75 & 4.53 & & & 0 & 1.93 \\
\hline 141 & & & 3.57 & 3.56 & 4.65 & 5.72 & 6.75 & 6.82 & 8.08 & & & 0.01 & 9.94 \\
\hline 153 & & & & 0 & 0.03 & 0.08 & 0.31 & 0.37 & 0.77 & & & & 0.01 \\
\hline 154 & & & & 0.02 & 1.17 & 2.14 & 2.62 & 2.62 & 3.10 & & & & 0.04 \\
\hline 155 & & & & 0.88 & 3.46 & 4.85 & 5.39 & 5.25 & 6.21 & & & & 0.08 \\
\hline 167 & & & & 0 & 0.07 & 0.03 & 0.58 & 0.26 & 0.56 & & & & \\
\hline 168 & & & & 0.01 & 0.70 & 1.57 & 2.11 & 2.51 & 3.37 & & & & \\
\hline 169 & & & & 0.67 & 1.92 & 3.98 & 4.64 & 4.76 & 5.65 & & & & \\
\hline 181 & & & & & 0 & 0.08 & 0 & 0.11 & 0.30 & & & & \\
\hline 182 & & & & & 0.01 & 0.77 & 1.53 & 1.66 & 2.13 & & & & \\
\hline 183 & & & & & 0.06 & 2.51 & 4.02 & 3.83 & 4.30 & & & & \\
\hline 195 & & & & & 0 & 0.03 & 0 & 0.08 & 0.05 & & & & \\
\hline 196 & & & & & 0.10 & 0.39 & 1.21 & 1.60 & 2.34 & & & & \\
\hline 197 & & & & & 0.04 & 0.39 & 3.38 & 3.63 & 4.30 & & & & \\
\hline 209 & & & & & & 0 & 0 & 0.05 & 0.12 & & & & \\
\hline 210 & & & & & & 0.02 & 0.61 & 1.01 & 1.66 & & & & \\
\hline 211 & & & & & & 0.08 & 2.13 & 2.87 & 3.43 & & & & \\
\hline 223 & & & & & & 0 & 0 & 0.03 & 0.05 & & & & \\
\hline 224 & & & & & & 0.08 & 0.43 & 0.85 & 1.54 & & & . & \\
\hline 225 & & & & & & 0.14 & 1.32 & 2.48 & 3.38 & & & & \\
\hline 237 & & & & & & & 0 & 0.05 & 0.08 & & & & \\
\hline 238 & & & & & & & 0.02 & 0.40 & 0.88 & & & & \\
\hline 239 & & & & & & & 0.11 & 1.44 & 2.73 & & & & \\
\hline 251 & & & & & & & 0 & 0 & 0.14 & & & & \\
\hline 252 & & & & & & & 0.03 & 0.39 & 0.88 & & & & \\
\hline 253 & & & & & & & 0 & 1.07 & 2.51 & & & & \\
\hline 265 & & & & & & & & 0 & 0 & & & & \\
\hline 266 & & & & & & & & 0.06 & 0.39 & & & & \\
\hline 267 & & & & & & & & 0.22 & 1.49 & & & & \\
\hline 279 & & & & & & & & 0 & 0 & & & & \\
\hline 280 & & & & & & & & 0.19 & 0.44 & & & & \\
\hline 281 & & & & & & & & 0.05 & 1.21 & & & & \\
\hline 293 & & & & & & & & & 0 & & & & \\
\hline 294 & & & & & & & & & 0.18 & & & & \\
\hline 295 & . & & & & & & & & 0.11 & & & & \\
\hline 307 & & & & & & & & & 0 & & & & \\
\hline 308 & & & & & & & & & 0.33 & & & & \\
\hline 309 & & & & & & & & & 0.14 & & & & \\
\hline
\end{tabular}


Table II $\Sigma 41, \sum 42$ 扔よび $\Sigma 43$

\begin{tabular}{lrrr}
\hline \multicolumn{1}{c}{ 炭化水素 } & $\sum 41$ & $\sum 42$ & $\sum 43$ \\
\hline$n$-hexane & 86.2 & 85.0 & 178.2 \\
$n$-octane & 89.4 & 86.3 & 281.1 \\
$n$-decane & 97.1 & 79.7 & 301.7 \\
$n$-dodecane & 116.8 & 88.6 & 323.8 \\
$n$-tetradecane & 132.8 & 94.3 & 458.9 \\
$n$-hexadecane & 138.9 & 91.3 & 481.6 \\
$n$-octadecane & 150.0 & 97.3 & 509.1 \\
$n$-eicosane & 164.7 & 97.4 & 520.5 \\
$n$-docosane & 176.6 & 107.8 & 524.9 \\
2-methyl heptane & 99.1 & 107.6 & 321.5 \\
2,2-dimethyl heptane & 73.4 & 92.5 & 272.3 \\
3,3,5-trimethyl heptane & 84.4 & 66.6 & 390.1 \\
2-methyl decane & 142.4 & 110.4 & 467.3 \\
\hline
\end{tabular}

Table III 前報の $\sum 41, \sum 42$ 扎よび $\Sigma 43$

\begin{tabular}{|c|c|c|c|}
\hline 炭化水素 & $\sum 41$ & $\Sigma 42$ & $\Sigma 43$ \\
\hline$n$-hexane & 91.1 & 86.4 & 183.4 \\
\hline$n$-heptane & 84.7 & 85.9 & 241.4 \\
\hline$n$-octane & 86.2 & 86.0 & 295.4 \\
\hline$n$-nonane & 91.7 & 85.1 & 344.2 \\
\hline 2 -methyl pentane & 71.7 & 106.4 & 223.2 \\
\hline 3-methyl pentane & 107.0 & 108.2 & 170.2 \\
\hline 2,2-dimethyl butane & 82.9 & 36.3 & 277.1 \\
\hline 2,3-dimethyl butane & 77.3 & 154.9 & 211.1 \\
\hline 2-methyl hexane & 84.5 & 105.7 & 279.7 \\
\hline 3-methyl hexane & 85.1 & 108.0 & 251.7 \\
\hline 3-ethyl pentane & 74.2 & 101.4 & 283.7 \\
\hline 2,2-dimethyl pentane & 85.9 & 65.8 & 329.1 \\
\hline 2,3 -dimethyl pentane & 101.9 & 141.5 & 237.8 \\
\hline 2,4-dimethyl pentane & 91.1 & 99.5 & 302.1 \\
\hline 3,3 -dimethyl pentane & 138.3 & 104.4 & 717.7 \\
\hline 2-methyl heptane & 84.2 & 110.0 & 319.1 \\
\hline 3-methyl heptane & 93.3 & 110.2 & 318.4 \\
\hline 4-methyl heptane & 71.3 & 108.7 & 286.6 \\
\hline 3-ethyl hexane & 83.0 & 107.0 & 334.8 \\
\hline 2,2 -dimethyl hexane & 108.4 & 94.0 & 335.2 \\
\hline 2,3-dimethyl hexane & 87.2 & 130.0 & 278.0 \\
\hline 2,4-dimethyl hexane & 97.0 & 86.7 & 354.2 \\
\hline 2,5-dimethyl hexane & 67.5 & 65.5 & 282.0 \\
\hline 3,3-dimethyl hexane & 64.4 & 106.0 & 321.3 \\
\hline 3,4-dimethyl hexane & 95.7 & 139.7 & 233.0 \\
\hline 2-methyl 3-ethyl pentane & 92.1 & 126.9 & 275.4 \\
\hline 3-methyl 3 -ethyl pentane & 83.5 & 44.1 & 383.2 \\
\hline
\end{tabular}

$\sum 41$ についてみると, ノルマルパラフィンおよびィ ソパラフィンともに $\mathrm{C}_{6}$ から $\mathrm{C}_{10}$ までは 100 以下でば らつきは大きいが一定值である。しかし， $\mathrm{C}_{11}$ 以上では 炭素数の增加にしたがって $\Sigma 41$ も大きくなる.

イオン量と炭素数との関係については， $\Sigma 41, \sum 42$ および した報告はみられないが，全イオン量と炭素数について は報告があり, 炭素数が $\mathrm{C}_{10}$ 以下のパラフィン系炭化水 素について, 同一炭素数の異性体の全イオン量は等し く, 炭素数の增加とともに全イオン量は増加することを

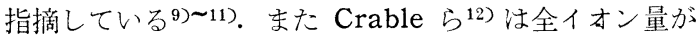
次式で示され，分子量とともに増加することを推定し， $\mathrm{C}_{10}$ 以下の炭化水素の測定值が推定結果と一致すること を示した。

炭化水素の基礎化学構造（たとえば $\mathrm{C}-\mathrm{C}, \mathrm{C}=\mathrm{C}, \mathrm{C} \equiv \mathrm{C}$, 〈〉-，〈〉-など）のイオン化断面積を $Q$, その 質量数を $M_{B}$, 炭化水素の分子量を $M$, 比例定数を $k$ とすると，全イオン量 $T_{P}$ は，

$$
T_{P}=k\left(Q-0.44 M_{B}\right)+0.44 k M
$$

この式から全イオン量は分子量とともに增加し，分子 量と直線関係にあることとなり, 測定值もよく一致して いる. $\mathrm{C}_{10}$ までの部分的の合計イオン量について考察す ると， $\sum 41$ は大体一定であり， $４ 3$ はイソパラフィ ンでは異性体によってばらつきが大きいが，一般的に法 炭素数とともに增加する. また $\sum 42$ はノルマルとイソ パラフィンでは異なるが,ノルマルパラフィンあるいは 側鎖が 1 個のイソパラフィンでは一定值になること，お よび $\sum 41 ， \sum 42$ および $\Sigma 43$ が主なイオンであるこ とから考えると, 炭素数とともに全イオン量を増加させ るイオングループは $\sum 43$ となり，(1) 式に近似した炭 素数による增加荌示す. $\sum 43$ は $\mathrm{C}_{10}$ 以上においても, Table II のとおり炭素数とともに増加卞る. 次に $\sum 43$ と分子量との比安各炭化水素について求的てみる,

Fig. 1 のようになる.

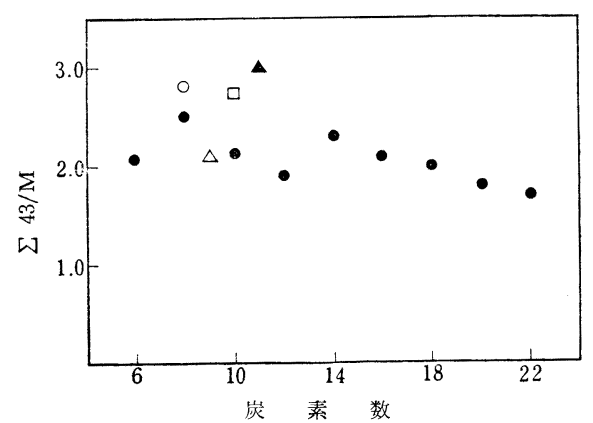

Fig. 1 炭化水素の $\sum 43 / \mathrm{M}$

- n-paraffin $\bigcirc 2$-methyl heptane $\triangle 2,2$-dimethyl heptane

A 3,3,5-trimethyl heptane $\square$ 2-methyl decane

この結果，ノルマルパラフィンは約 2.0 に近似してお り，炭素数が多くなるとやや小さくなる傾向がある（た とえば $n-\mathrm{C}_{22} \mathrm{H}_{46}$ は 1.69).このことは $\Sigma 43$ は炭素数 が多くなると一定值に近づくものと推定される・イソパ ラフィンは測定值が少ないためにはっきりしたことはわ 
からないが，側鎖 1 個の炭化水素の $\sum 43 / M$ の値はノ ルマルパラフィンより大きく，かつ，一定值となり，側 鎖 2 㮯以上の炭化水素の值は一定值とはならないものと 推定され， $\Sigma 42$ とよく近似した傾向のようである.

\section{$4 \cdot 2 \sum 42$}

Table III では $\Sigma 42$ の值はノルマルパラフィンが 86 に近似し，イソパラフィンのうち側鎖 1 個の炭化水 素が 107 に近似した。 また，側鎖 2 個のものは一定值に ならず，2 個以上のものも同様と推定された. Table II では $\mathrm{C}_{12}$ まではノルマルおよびィソパラフィンともに Table III と全く同一結果と学る. 次に， $\mathrm{C}_{14}$ 以上の, ルマルパラフィンでは, 若干であるが炭素数とともに増 加する. しかし，この増加は $\sum 42$ の值学使用するタイ プ分析が不可能なほど大きくはないと考えられる。ま た，イソパラフィンについては $\mathrm{C}_{11}$ まで測定したのみで あるが，イソパラフィンの $\sum 42$ も炭素数とともに增加 するものと推定されることから， $４ 2$ によるタイプ分 析は可能であろう.

側鎖が 3 個の $3,3,5$-トリメチルヘプタンの $\Sigma 42$ は 66.6 となり，側鎖 2 個のイソパラフィンと同じく側鎖 1 個のイソパラフィンの值からはずれるものと考えられ ๖.

\section{$4 \cdot 3$ 分子イオン}

分子イオンについてはノルマルパラフィンが㟶素数と ともに減少与る傾向があり，イソパラフィンも測定值は 少ないが同一の結果である.しかし，その值はタイプ分 析法を適用しうる大きさを有している．側鎖 1 個のイソ パラフィンと 2 個以上のイソパラフィンとの差も前回の 測定結果と同一となった. Table IV に分子イオンの值 $\left(a_{m j} S_{j} / S_{\mathrm{hex}}\right)$ を示す.

Table IV 分子イオン $\left(a_{m j} S_{j} / S_{\mathrm{hex}}\right)$

\begin{tabular}{lc}
\hline \multicolumn{1}{c}{ 炭化水素 } & $a_{m j} S_{j} / S_{\text {hex }}$ \\
\hline$n$-hexane & 17.80 \\
$n$-octane & 11.16 \\
$n$-decane & 10.43 \\
$n$-dodecane & 7.56 \\
$n$-tetradecane & 9.90 \\
$n$-hexadecane & 8.31 \\
$n$-octadecane & 7.11 \\
$n$-eicosane & 4.91 \\
$n$-docosane & 5.04 \\
2-methyl heptane & 4.68 \\
2,2-dimethyl heptane & 0.38 \\
3,3,5-trimethyl heptane & 0.06 \\
2-methyl decane & 2.52 \\
\hline
\end{tabular}

\section{$4 \cdot 4$ 質量スペクトルの型}

パタン係数からノルマルヘキサンの M/e 57 を基準と した相対值を求め，关れを質量数順に図示するとパラフ ィン系炭化水素の構造と密接な関係が得られる。すなわ ち，ノルマルパラフィンは炭素数に無関係で，いずれの ノルマルパラフィンも同一の型となり，イソパラフィン とは異なる・イソパラフィンのなかでは側鎖 1 個のもの と 2 個以上のものとの間に差があることがわかる. Fig. 2, Fig. 3 および Fig. 4 にノルマルパラフィン, 側鎖 1 個のイソパラフィンおよび側鎖 2 個以上のイソパラフ ィンの代表的な型を示す.

$a_{l j} S_{j} / S_{\text {hex }}$ の図型は Fig. 2, Fig. 3 および Fig. 4 からわかるようにいずれも同一である.ノルマルパラフ ィンとイソパラフィンで差のあるものは $a_{l{ }^{\prime} j} S_{j} / S_{\mathrm{hex}}$ お

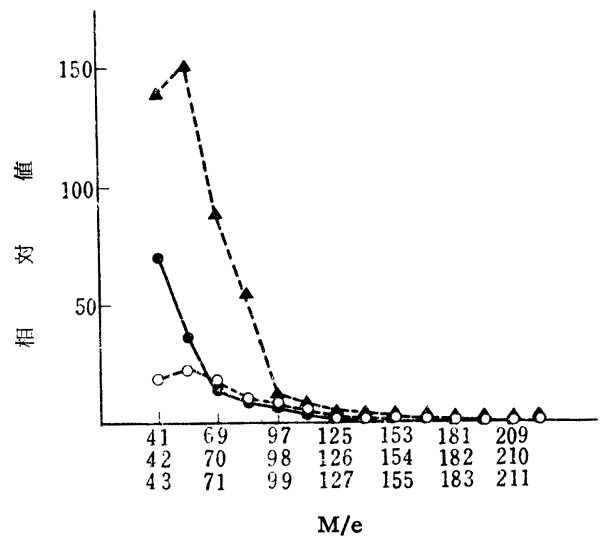

Fig. $2 n$-hexadecane の質量スペクトル $\begin{array}{llll}\text {-- } & a_{l j} S_{j} / S_{\text {hex }} & \text {.-O.- } a_{l^{\prime} j} S_{j} / S_{\text {hex }} \\ \text {--A-. } & a_{l^{\prime \prime} j} S_{j} / S_{\text {hex }}\end{array}$

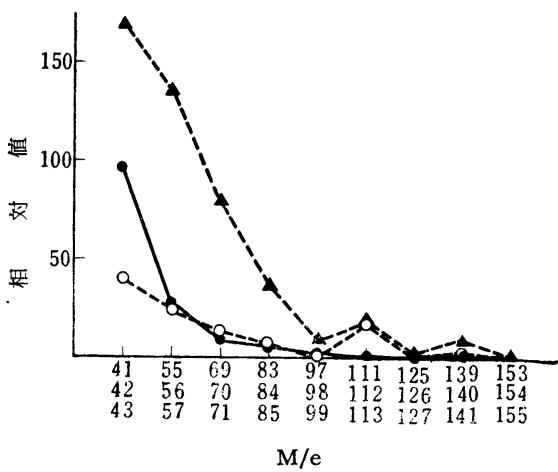

Fig. 3 2-methyl decane の資量スペクトル

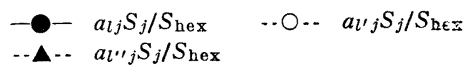




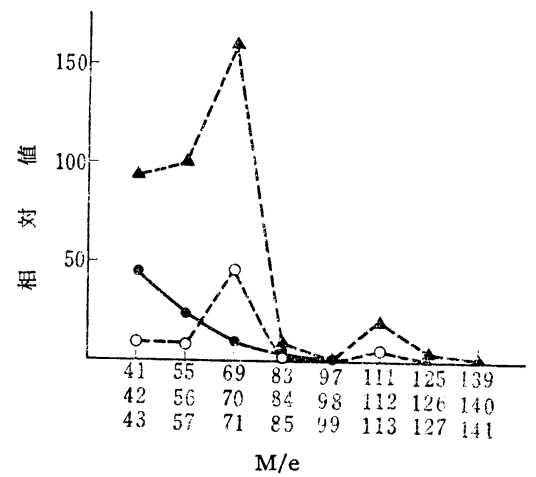

Fig. 4 3,3,5-trimethyl heptane の贔量スペクトル

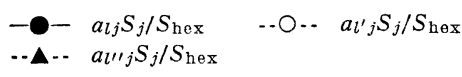

よび $a_{l,{ }_{j}} S_{j} / S_{\mathrm{hex}}$ であり，ノルマルパラフィンではこ れらが $a_{l j} S_{j} / S_{\mathrm{hex}}$ と等しいのに対し，イソパラフィン では山ができ，山の位置，大きさおよび数は側鎖と密接 な関係がある。また，側鎖 2 個以上のものと 1 個のもの との差は 2 個以上のものが低質量位置に大きな山をつく ることであり，これは電子衝揧による解離過程からも推 定できる.ノルマルパラフィンの $\mathrm{C}_{n} \mathrm{H}_{2 n+1}+$ の図型につ いては O’Neal ら ${ }^{13)}$ が報告しているが，全く同一の結 果になった。 これらイオングループの図型は定性分析に 応用できるものと考えられ, 特に炭化水素のタイプの判 定に注有効であろう.

\section{$4 \cdot 5$ タイプ分析法}

前項までの考察の絬果，分子イオンおよび $\Sigma 42$ によ ってノルマルパラフィンおよび側鎖の1個のみのイソパ ラフィンのタィプ分析法を $\mathrm{C}_{12}$ 以上にも適用できること が判明した。

解析に使用する分子イオンおよび キサンの M/e 57 を 100 として求めた相対ピーク量よ り計算し，ノルマルパラフィンおよびイソパラフィンと もに炭素数および異性体の平均值を用いる. 平均值を求 める際の炭素数範囲は試料の質量スペクトルから決定す る. また, 試料の分子イオン量は試料中の全分子イオン の合計值とする.

上記分析法を合成試料に適用し検討した. Table V および Table VI は3 回の測定の平均值である.この 結果, $\mathrm{C}_{12}$ 以上への適用が可能である.

最後に, 本研究な行なうにあたって, 御協力下さった 日立製作所那珂工場の牧野勇夫部長敄よび質量分析計担 当のかたがたに感謝いたします.

(昭和 37 年 4 月, 日本化学会第 15 年会に抽いて発表)
Table V 合成試料 No. 1 の分析結果（vol\%)

\begin{tabular}{|c|c|c|c|}
\hline 炭化水素 & 合成代 & & 分㟁啃 \\
\hline $\begin{array}{l}n \text {-hexane } \\
n \text {-decane } \\
n \text {-dodecane } \\
n \text {-octadecane }\end{array}$ & $\left.\begin{array}{r}9.7 \\
39.6 \\
36.1 \\
10.0\end{array}\right\}$ & 95.4 & $95.7 \pm 0.83$ \\
\hline $\begin{array}{l}2 \text {-methyl heplane } \\
2 \text {-methyl decane }\end{array}$ & $\left.\begin{array}{l}2.3 \\
2.3\end{array}\right\}$ & 4.6 & $4.3 \pm 0.83$ \\
\hline
\end{tabular}

Table VI 合成試料 No. 2 の分析結果（vol\%)

\begin{tabular}{|c|c|c|c|}
\hline 炭化水素 & \multicolumn{2}{|c|}{ 合成值 } & 分析值 \\
\hline $\begin{array}{l}n \text {-hexane } \\
n \text {-decane } \\
n \text {-dodecane } \\
n \text {-octadecane }\end{array}$ & $\left.\begin{array}{r}7.7 \\
31.4 \\
28.6 \\
8.0\end{array}\right\}$ & 75.7 & $74.6 \pm 1.63$ \\
\hline $\begin{array}{l}\text { 2-methyl heptane } \\
\text { 2-methyl decane }\end{array}$ & $\left.\begin{array}{l}11.0 \\
13.3\end{array}\right\}$ & 24.3 & $25.4 \pm 1.63$ \\
\hline
\end{tabular}

\section{文献}

1) K. H. Nelson, M. D. Grimes, B. J. Heinrich: "Division of an Analytical Chemistry", 130 th Meeting, A. C. S., Atlantic City, N. J., U. S. A., 1956 年 9 月.

2) R. D. Schwartz, D. J. Brasseaux : "Division of an Analytical Chemistry", 131th Meeting, A. C. S., Miami, Fla., U.S. A., 1957 年 4 月.

3) E. V. Truter : Chem. Proc. Eng., 35, No. 3, 75 (1954).

4) W. Leith : Anal. Chem., 23, 493 (1951).

5) H. Sobcov : ibid., 30, 314 (1958).

6) W. C. Ferguson, H. E. Howard : ibid., 30, 314 (1958).

7) 大島昌三，西下孝夫：質量分析研究会昭和 36 年 度大会, 1961 年 10 月; 質量分析に投稿中.

8) 大島湿三，勝又 章 : 本誌, 11，850 (1962).

9) E. G. Bloom, F. L. Mohler, J. H. Lengel, C. E. Wise : J. Research Nat. Bur. Standards, 41, 129 (1948).

10) F. L. Mohler, E. G. Bloom, L. M. Williamson, C. E. Wise, E. J. Wells : ibid., 43, 533 (1949).

11) F. L. Mohler, L. M. Williamson, C. E. Wise, E. J. Wells, H. M. Dean, E. G. Bloom : ibid., 44, 291 (1950).

12) G.F. Crable, N. D. Coggeshall : Anal. Chem., 30, 310 (1958).

13) M. J. O’Neal, T. P. Wier : ibid., 23, 830 (1951).

$$
\text { ș }
$$

Type analysis of $n$-paraffines and iso-paraffines by mass spectrometry. Shozo Oshima (Research Center, Maruzen Oil Co.)

In the earlier papers reporting the massspectrometric type-analysis of paraffines, the objects were confined in $\mathrm{C}_{6} \sim \mathrm{C}_{11}$ normal-paraffines or $i s o$-paraffines with only one branch.

The author presents in this paper the mass- 
spectra of $\mathrm{C}_{6} \sim \mathrm{C}_{22}$ paraffines obtained by a mass spectrometer of high resolving power with a high temperature sample introduction device.

The results indicate that the type analysis with the combining use of the total sum of peak heights of $\mathrm{C}_{n} \mathrm{H}_{2 n}$ ion of $\mathrm{M} / \mathrm{e}>42$ (relative values with $\mathrm{M} / \mathrm{e} 57$ of $n$-hexane as the base peak.) and the molecular ion is successfully applicable to $\mathrm{C}_{12} \sim \mathrm{C}_{22}$ paraffines.

(Received Apr. 13, 1962) 